\title{
Comparative toxicity of new insecticides generations against tomato leafminer Tuta absoluta and their biochemical effects on tomato plants
}

Mohamed Abdel-Hady Kandil ${ }^{1}$, Elham Ahmed Sammour ${ }^{2}$, Nahed Fawzy Abdel-Aziz², Essam Abd El Maguied Agamy ${ }^{1}$, Ahmed Mohamed El-Bakry ${ }^{2}$ and Nasr Mohamed Abdelmaksoud ${ }^{2,3^{*}}$ (1)

\begin{abstract}
Background: The physico-chemical properties along with the insecticidal potency of seven non-traditional insecticides from different classes compared with three conventional insecticides were assessed versus Tuta absoluta (Meyrick) (Lepidoptera: Gelechiidae) below laboratory and field conditions.
\end{abstract}

Results: All non-conventional insecticides passed the physico-chemical properties except Actra (thiamethoxam) which failed in $\mathrm{pH}$ test. Moreover, all conventional insecticide failed these characteristics. The laboratory assessment of the examined insecticides demonstrated that Emperor (Emamectin benzoate) and Coragen (Chlorantraniliprole) were the most superior $\left(\mathrm{LC}_{50}=0.26\right.$ and $0.46 \mathrm{mg} \mathrm{L}^{-1}$, respectively), followed by Radiant (Spinetoram), Vapcomic (Abamectin), and Challenger (Chlorfenapyr) $\left(\mathrm{LC}_{50}=0.59,0.60\right.$, and $24.07 \mathrm{mg} \mathrm{L}^{-1}$, respectively). Accordingly, these most potent insecticides were evaluated under field circumstances. The levels of insect infestation reduced by 98.74 and $95.51 \%$ after 7 days of spraying for the most effective insecticides, Emperor and Coragen, respectively, while the other examined insecticides were at par with one another. Concerning the biochemical effects of the most potent insecticides on tomato plants, all treatments induced promising effect on the photosynthetic pigments. In addition, they significantly minimized the activity of the enzymatic and non-enzymatic antioxidants. The most potent biochemical effects were ascribed to Emperor and Coragen insecticides. These two insecticides proved again the maximum total and marketable yields. Moreover, Challenger, Radiant, and Vapcomic revealed minor differences with Emperor and Coragen of the efficiency and marketable yield.

Conclusions: The results proved that the examined insecticides, Challenger, Radiant, Vapcomic, especially, Emperor and Coragen can be successfully used in the IPM tactic against T. absoluta insect.

Keywords: Insecticides, New generations, Tuta abso/uta, Biochemical effects, Photosynthetic, Antioxidant enzymes, Marketable yield

\footnotetext{
* Correspondence: nm_nrc@yahoo.com

${ }^{2}$ Department of Pests and Plant Protection, National Research Centre, Cairo,

Egypt

${ }^{3}$ Agricultural and Biological Research Division, Pests and Plant Protection

Department, National Research Centre, Cairo, Egypt

Full list of author information is available at the end of the article
}

\section{Springer Open}

(c) The Author(s). 2020 Open Access This article is licensed under a Creative Commons Attribution 4.0 International License, which permits use, sharing, adaptation, distribution and reproduction in any medium or format, as long as you give appropriate credit to the original author(s) and the source, provide a link to the Creative Commons licence, and indicate if changes were made. The images or other third party material in this article are included in the article's Creative Commons licence, unless indicated otherwise in a credit line to the material. If material is not included in the article's Creative Commons licence and your intended use is not permitted by statutory regulation or exceeds the permitted use, you will need to obtain permission directly from the copyright holder. To view a copy of this licence, visit http://creativecommons.org/licenses/by/4.0/. 


\section{Introduction}

Tomato plant (Solanum lycopersicum L.) is among the most crucial edible and nutritious vegetable crops in Egypt. It grows throughout the year as an economic crop by vegetable growers, both in a small and commercial scale. Both fresh and processed tomato cultivars are preferable and considered as an economic crop. The average yield of tomato in Egypt is 40 ton ha $\mathrm{ha}^{-1}$ FAOSTAT (2017). The agricultural production of tomato is considerably limited by many factors involving insect pests and diseases. The new destructive pest, tomato leaf miner Tuta absoluta (Meyrick), is among the most serious insect pests with limited tomato production. It is an invasive insect that causes significant losses in tomato production in several regions, whether in open field or greenhouses (CABI 2019). T. absoluta larvae attack tomato plants during all their growth stages. It can infest leaves, flower, stem, and fruit, causing considerable losses in tomatoes (Mollá et al. 2011). In Egypt, the yield loss reaches to $100 \%$ in some locations, if there were no control measures taken (CABI 2019). T. absoluta is a hard insect to be managed due to its distinctive biology and demeanor. The larvae mine in the leave mesophyll forming irregular, papery mines. It more mines apical buds and stalk (Arnó and Gabarra 2010). The insect has a high reproductive potential. The use of chemical insecticides, traditional or unconventional, is the main control strategy for $T$. absoluta, which provides 95\% control at 14-21 days after treatment (DAT). Each of eggs and larvae is significantly reduced, where repeated applications are recommended (CABI 2019; Guedes and Picanço 2012). The $T$. absoluta populations were resistant to pyrethroid, carbamate, and organophosphate insecticides (Bala et al. 2019). However, recent classes of insecticides offered proper control of this pest such as abamectin, chlorfenapyr, indoxacarb, spinosad, and imidacloprid (Guedes et al. 2019; Tayeb et al. 2018). The superiority of the non-traditional chemical insecticides over the conventional insecticides may be due to several reasons; these compounds are newly introduced to the field of plant protection exhibited novel and different modes of action that prevent or delay build up resistance against them, beside the intensive employ of the conventional insecticides. Consequently, the objective of the present study is to evaluate some new insecticides generations on $T$. absoluta in comparison with conventional insecticides from different groups under laboratory and field conditions, as well as the potency of these insecticides in diminish the insect infestation through determination of the enzymatic and non-enzymatic antioxidants in tomato plants.

\section{Materials and methods Insecticides}

Seven insecticides belong to different new generations as avermectins (Emperor 0.5\% EC, Shandong Jingbo Agrochemical Co., China; Vapcomic 1.8\% EC, Vapco, Jordan), chlorfenapyr (Challenger 24\% SC, BASF LTD., Egypt), diamide (Coragen 20\% SC, Dupont, Canada), neonicotinoids (Actara 25\% WG, Syngenta, Agro, Egypt; Imaxi 35\% SC, Rotam agrochemical, Hong Kong), and spinosyns (Radiant 12\% SC, Dow Agrosciences, England), along with 3 insecticides affiliated to conventional groups of organophosphates (Pestban 48\% EC, Agrochem, Egypt), Organophosphates + pyrethroids (Action Phos 50\% EC, Agrochem, Egypt) and pyrethroids (Delta Plus 50\% EC, Delta Plus Co., Egypt) were evaluated against T. absoluta.

\section{Insect}

The populations of $T$. absoluta were established using larvae collected from untreated tomato fields, in Elfashn Village, Bani Sweif Governorate. The stock was maintained under laboratory conditions, and leaves of tomato were used to feed the insect larvae during the experiment.

\section{The physico-chemical properties \\ Emulsion stability test}

The emulsion stability test was carried out according to WHO specifications (WHO 1979). Into a $250 \mathrm{ml}$ beaker, 75-80 $\mathrm{ml}$ of tested water (distilled, soft, and hard water) was poured. Five milliliters of the emulsifiable concentrate formulation was added by a pipette, while stirring with a glass rod. The beaker contents were stirred with a glass rod then completed to $100 \mathrm{ml}$ by addition of the tested water, while the stirring was continuous. The beaker contents are poured immediately into a clean, dry, graduated $100 \mathrm{ml}$ cylinder. The cylinder was kept at 30$31{ }^{\circ} \mathrm{C}$ for $1 \mathrm{~h}$ and examined for any creaming or separation.

\section{Foam test}

The emulsion stability test was carried out to measure the foam amounts formed on the emulsion surface in the cylinder after $5 \mathrm{~min}$.

\section{Wettability test}

The test was carried out according to CIPAC specifications (Dobrat and Martijn 1995). Into a $250 \mathrm{ml}$ beaker having an internal diameter of $6-6.5 \mathrm{~cm}, 100 \mathrm{ml}$ of the tested water (distilled, soft, and hard water) were poured. Five grams of Actara insecticide were weighted and added at once by dropping them on the water, from a position level with the rim of the beaker, without undue agitation of the liquid surface. The time taken from the 
powder added until completely wetted was calculated to the nearest second.

\section{pH test}

The test was carried out according to CIBAC specifications (Dobrat and Martijn 1995). One gram of the tested formulation was weighed and transferred to a measuring cylinder $(100 \mathrm{ml})$ containing about $50 \mathrm{ml}$ distilled water. The cylinder was made up to $100 \mathrm{ml}$ and shook vigorously for 1 min then it was allowed to settle. The $\mathrm{pH}$ of the supernatant liquid was measured.

\section{The insecticidal efficiency against 2nd instar larvae of Tuta absoluta \\ Laboratory experiments}

The biological efficacy of the tested insecticides was evaluated against 2nd larval instar of T. absoluta by leaf dipping method (IRAC 2017). Leaves of tomato plants (from un-infested green house) were immersed individually in a series of concentrations of each tested compound for $3 \mathrm{~s}$. The leaves were placed in Petri dishes with 10 larvae. Four replicates were carried out for each treatment. Larvae in control treatment were fed on leaves treated only with water. The mortality percentages were recorded after $48 \mathrm{~h}$ of treatment. Data were corrected for mortality from control by Abbott (Abbott, 1925) The mortality data were subjected to Probit analysis to obtain the $\mathrm{LC}_{90}$ (Finney 1971).

\section{Abbott formula}

$$
\text { Corrected } \%=1-\frac{\text { Insect population in treatment after treatment }}{\text { Insect population in control after treatment }} \times 100
$$

\section{Field experiment}

Field experiments were carried out on infested tomato plants with $T$. absoluta cultivated in Elfashn Village, Bani Sweif Governorate, from January to May 2016. A known area was cultivated with tomato plants and divided into plots; each one is $42 \mathrm{~m}^{2}$. Tomato plants were sprayed by three folds of $\mathrm{LC}_{90}$ values that previously estimated for the most promising insecticides (Coragen, Emperor, Challenger, Radiant, and Vapcomic). Samples of treated plants were taken before application and after periods of $(1,3,5$, and 7 days). Another sample of nontreated infested plants were also taken after the same previously tested periods and used as control. The reduction percentages were calculated according to Henderson and Tilton (1955). Larvae were considered dead if they were unable to move.

$$
\% \text { Reduction }=1-\frac{\mathrm{Ta} \mathrm{X} \mathrm{Cb}}{\mathrm{Tb} \mathrm{X} \mathrm{Ca}} \times 100
$$

Where
$T_{\mathrm{a}}$ is the number of larvae/10 leaflets in the treatment after application.

$T_{\mathrm{b}}$ is the number of larvae/10 leaflets in the treatment before application.

$\mathrm{C}_{\mathrm{a}}$ is the number of larvae/10 leaflets in check after application.

$C_{b}$ is the number of larvae/10 leaflets in check before application.

The side effects of the most promising insecticides on some biochemical parameters of tomato plants

The activity of the enzymatic and non-enzymatic antioxidants of tomato-treated plants was evaluated. Leave samples were taken before spraying and after periods of 1, 3, 5, and 7 days. Another sample from non-treated infested plants was taken after the same previously tested periods and used as a control.

\section{Plant tissue preparation}

Enzyme extracts were prepared according to the method described by Chen and Wang (2006). Leaf tissues were homogenized in ice-cold phosphate buffer $(50 \mathrm{mM}, \mathrm{pH}$ 7.8), followed by centrifugation at $8000 \mathrm{rpm}$ and $4{ }^{\circ} \mathrm{C}$ for $15 \mathrm{~min}$. The supernatant was used immediately to determine the activities of the tested enzymes.

\section{Super oxide dismutase (SOD)}

SOD (EC 1.12.1.1) activity was spectro-photometrically assayed at $560 \mathrm{~nm}$ by nitro-blue-tetrazolium (NBT) reduction method (Chen and Wang 2006). The reaction mixture $(3 \mathrm{ml})$ contained $150 \mu \mathrm{l}$ riboflavin $(13 \mu \mathrm{M}), 2.5 \mathrm{ml}$ methionine $(13 \mu \mathrm{M}), 250 \mu \mathrm{L}$ NBT $(63 \mu \mathrm{M}), 50 \mu \mathrm{l}$ phosphate buffer (50 mM, pH 7.8), and $50 \mu \mathrm{l}$ enzyme extract. One unit of SOD activity was defined as the amount of enzyme protein required for inhibition of 50\% reduction of NBT.

\section{Catalase (CAT)}

CAT (EC 1.11.1.6) activity was determined spectrophotometrically by following the decrease in absorbance at $240 \mathrm{~nm}$ (Chen and Wang 2006). The mixture (3 ml) contained $1.9 \mathrm{ml}$ phosphate buffer (50 mM, pH7.0), 100 $\mu \mathrm{l}$ enzyme extract, and $1 \mathrm{ml}$ of $0.3 \% \mathrm{H}_{2} \mathrm{O}_{2}$. The reaction was initiated by adding enzyme extract. One unit of CAT activity was defined as 0.01 deductions in absorbance at $240 \mathrm{~nm}$ per minute. The enzyme activity was calculated by Kong et al. (1999).

\section{Poly phenol oxidase (PPO)}

PPO (EC 1.10.3.1) activity was determined using a spectrophotometric method based on an initial rate of increase in absorbance at $410 \mathrm{~nm}$ (Soliva et al. 2000). Phosphate buffer solution $\mathrm{pH} 7(0.1 \mathrm{M}, 1.95 \mathrm{ml}), 1 \mathrm{ml}$ of $0.1 \mathrm{M}$ pyrogallol as a substrate and $50 \mu \mathrm{l}$ of the enzyme extract were pipetted into a test tube and mixed thoroughly. Then, the mixture 
was rapidly transferred to cuvette. The absorbance at 410 $\mathrm{nm}$ was recorded continuously at $25^{\circ} \mathrm{C}$ for $5 \mathrm{~min}$.

\section{Glutathione S-transferase (GST)}

The activity of GST was determined in supernatant (as enzyme solution) and measured spectrophotometrically by measuring the conjugation of CDNB (1chloro-2,4-dinitrobenzene) with glutathione according to Habig et al. (1974). The conjugation is accompanied by an increase in absorbance at $340 \mathrm{~nm}$. The rate of increase is directly proportional to the GST in the sample.

\section{Total phenolic compounds content}

A known weight of the fresh leaf tissue samples was extracted with $85 \%$ cold methanol $(\mathrm{v} / \mathrm{v})$ for three times at 0 ${ }^{\circ} \mathrm{C}$. The combined extracts were collected, dried under vacuum, and made up to a known volume with distilled water. Total phenols were determined using FolinCiocalteu reagent, and then $0.5 \mathrm{ml}$ extract was added to $0.5 \mathrm{ml}$ Folin reagent, shaken, and allowed to stand for 3 $\mathrm{min}$. Then, $1 \mathrm{ml}$ of saturated sodium carbonate was added to each tube followed by distilled water, shaken, and allowed to stand for $60 \mathrm{~min}$. The optical density was determined at $725 \mathrm{~nm}$ using spectrophotometer as described by (Diaz and Martin 1972).

\section{Photosynthetic pigments content}

Chlorophyll a, chlorophyll b, and total carotenoids contents were extracted from $1 \mathrm{~g}$ of longitudinal sections of fresh leaves and grounded in a mortar in $85 \%$ acetone. The optical density of the solution was recorded at 663 , 644, and $452.5 \mathrm{~nm}$ for chlorophyll a, b, and carotenoids, respectively, measuring spectrophotometrically according to Metzner et al. 1965, and their levels were calculated according to the formula of Harmut and Lichtenthaler (1987). Values of photosynthetic pigments were expressed in $\mathrm{mg} / \mathrm{g}$ fresh weight.

\section{Yield production}

At the harvest, yield of marketable healthy fruits was recorded. All fruits harvested from each plot throughout the harvest period (about five successive harvests) were weighted to calculate the total yield per feddan (ton/fed.), as well as the total cost and the net profit for feddan and for tons of tomato yield were also calculated. The income statement was used to estimate the profit of tomato production.

$$
\text { Increase of yield }(\%)=\frac{\text { Yield of treated tomato }- \text { Yield of untreated tomato }}{\text { Yield of untreated tomato }}
$$

\section{Cost of treatments}

Cost of various insecticides was taken as premarket price and labor charges were calculated. The total cost of spraying was calculated on the basis labor requirement per feddan per day. Market price of insecticides and labor charges were summed up to work out the total cost of application of each treatment. This cost was taken as an additional cost required for treatment against the pest.

\section{Additional income over control}

Additional income over control was calculated by multiplying the additional yield over untreated control with prevailing average local market price of tomato fruits.

\section{Net profit}

This was calculated by subtracting the additional cost required for treatment from the monetary benefit for each treatment.

\section{Cost benefit ratio}

The cost-benefit ratio (CBR) was calculated by dividing the net monetary return by total additional cost due to treatment.

\section{Statistical analysis}

Experimental design was a randomized complete block design. Data were subjected to one-way analysis of variance followed by Student-Newman-Keuls test to determine significant differences among mean values at the probability level of 0.05 . The concentration-mortality data were subjected to Probit analysis to obtain the $\mathrm{LC}_{90}$ values using the Statistical Package for the Social Sciences (SPSS) 25.0 software program (SPSS 2017). The values of $\mathrm{LC}_{50}$ were considered significantly different if the $95 \%$ confidence limits did not overlap.

\section{Results}

\section{The physico-chemical properties}

The chemical and physical characteristics of the tested insecticides (Action Phos, Delta Plus, Emperor, Pestban and Vapcomic as EC; Challenger, Coragen, Imaxi, and Radiant as SC; Actara as WG) were investigated. The findings of emulsion stability of EC formulations and foam formation of EC, SC, and WG formulations before storage, after cold and heat tropical storage with distilled, soft, and hard water were exhibited in Table 1. All the examined EC formulations except Action Phos and Pestban passed the emulsion stability, the volume of cream layer, if any, should not exceed $2 \mathrm{ml}$ (WHO 1979). The succeeded formulations did not record any separation layers before or after storage with all types of the tested water (Table 2). 
Table 1 Insecticides used for controlling Tuta absoluta

\begin{tabular}{|c|c|c|c|}
\hline Trade name & Common name & Chemical subgroup & Mode of entry \\
\hline \multicolumn{4}{|c|}{ Non-conventional insecticides } \\
\hline $\begin{array}{l}\text { Actara ( } 25 \% \text { WG) } \\
\text { Imaxi ( } 35 \% \text { SC) }\end{array}$ & Thiamethoxam imidacloprid & Neonicotinoids & $\begin{array}{l}\text { Translaminar } \\
\text { Systemic + translaminar }\end{array}$ \\
\hline $\begin{array}{l}\text { Emperor }(0.5 \% \text { EC) } \\
\text { Vapcomic }(1.8 \% \text { EC) }\end{array}$ & $\begin{array}{l}\text { Emamectin benzoate } \\
\text { Abamectin }\end{array}$ & Avermectins, milbemycins & Translaminar \\
\hline Coragen (20\% SC) & Chlorantraniliprole & Diamide & Systemic + contact \\
\hline Challenger (24\% SC) & Chlorfenapyr & Chlorfenapyr & Translaminar \\
\hline Radiant (12\% SC) & Spinetoram & Spinosyns & Translaminar \\
\hline \multicolumn{4}{|c|}{ Conventional insecticides } \\
\hline Action Phos (50\% EC) & Chlorpyrifos + LambadaCyhalothrin & Organophosphates + pyrethroids & Contact, stomach, and respiratory action \\
\hline Delta Plus (50\% EC) & Deltamethrin & Pyrethroids & Contact, stomach, and repellent properties \\
\hline Pestban (48\% EC) & Chlorpyrifos & Organophosphates & contact, stomach, and respiratory action \\
\hline
\end{tabular}

Again, Action Phos, and Pestban failed the foam formation test, while all other tested insecticides passed it. The limit of foam layer volume should not exceed $5 \mathrm{ml}$ (WHO 1979). It is noteworthy to mention that Challenger, Coragen, Radiant, and Vapcomic did not record any foam layers.

Wettability was determined for WG formulation, Actara. It passed the test, where the wetting time ranged from 4 to $6 \mathrm{~s}$ before storage, after cold and heat tropical storage with the tested water. The formulation should be completely wetted in $40 \mathrm{~s}$ (Dobrat and Martijn 1995).
Data provided in Table 3 showed $\mathrm{pH}$ values of the examined insecticides; before storage, after cold and heat tropical storage using distilled water. The $\mathrm{pH}$ of Actara and Action Phos were higher than 7, while it ranged from 4 to 7 of the other tested insecticides. Delta Plus and Vapcomic recorded the least $\mathrm{pH}$ values which ranged from 4 to 4.3 .

The aforementioned data revealed that Challenger, Coragen, Delta Plus, Emperor, Imaxi, Radiant, and Vapcomic passed all the physical and chemical characteristics at all different stages.

Table 2 Emulsion stability (EC formulations) and foam formation of the tested insecticides before storage, after cold, and heat tropical storage using distilled, soft, and hard water

\begin{tabular}{|c|c|c|c|c|c|c|c|c|c|}
\hline \multirow[t]{2}{*}{ Insecticides } & \multicolumn{3}{|c|}{ Before storage } & \multicolumn{3}{|c|}{ After cold storage } & \multicolumn{3}{|c|}{ After heat tropical storage } \\
\hline & D.W. & S.W. & H.W. & D.W. & S.W. & H.W. & D.W. & S.W. & H.W. \\
\hline \multicolumn{10}{|c|}{ Emulsion stability of EC formulations (separation ml) } \\
\hline Action Phos & 2.0 & 3.0 & 3.0 & 3.0 & 3.0 & 3.5 & 3.0 & 3.0 & 4.0 \\
\hline Delta Plus & - & - & - & - & - & - & - & - & - \\
\hline Emperor & - & - & - & - & - & - & - & - & - \\
\hline Pestban & 3 & 3.5 & 4.0 & 3.0 & 4.0 & 4.0 & 3.5 & 4.0 & 4.5 \\
\hline Vapcomic & - & - & - & - & - & - & - & - & - \\
\hline \multicolumn{10}{|l|}{ Foam formation (ml) } \\
\hline Actara (WG) & 0.5 & 0.5 & 1.0 & 0.7 & 0.6 & 0.8 & 0.5 & 0.6 & 1.0 \\
\hline Action Phos EC & 4.0 & 5.5 & 4.0 & 5.0 & 6.0 & 4.0 & 6.0 & 8.0 & 5.0 \\
\hline Challenger (SC) & - & - & - & - & - & - & - & - & - \\
\hline Coragen 20 (SC) & - & - & - & - & - & - & - & - & - \\
\hline Delta Plus EC & 1.0 & 1.0 & 1.0 & 1.0 & 0.7 & 1.0 & 1.0 & 1.0 & 1.2 \\
\hline Emperor EC & - & - & - & - & - & - & 1.0 & 1.0 & 1.5 \\
\hline Imaxi (SC) & 0.7 & 0.5 & 0.2 & 0.8 & 0.5 & 0.3 & 0.7 & 0.6 & 0.8 \\
\hline Pestban EC & 5.0 & 6.0 & 5.0 & 5.0 & 6.0 & 5.0 & 6.0 & 7.0 & 5.0 \\
\hline Radiant (SC) & - & - & - & - & - & - & - & - & - \\
\hline Vapcomic EC & - & - & - & - & - & - & - & - & - \\
\hline
\end{tabular}


Table $3 \mathrm{pH}$ of the examinedinsecticides before storage, after cold, and heat tropical storage

\begin{tabular}{llll}
\hline Insecticides & Before storage & After cold storage & After heat storage \\
\hline Actara (WG) & 8.1 & 8.2 & 7.9 \\
Action Phos & 7.3 & 7.3 & 7.2 \\
Challenger (SC) & 7.0 & 7.0 & 6.9 \\
Coragen 20 (SC) & 7.0 & 7.0 & 7.0 \\
Delta Plus & 4.2 & 4.0 & 4.3 \\
Emperor & 7.0 & 7.0 & 7.0 \\
Imaxi (SC) & 6.3 & 6.4 & 6.2 \\
Pestban & 5.2 & 5.3 & 5.4 \\
Radiant (SC) & 7.0 & 7.0 & 7.0 \\
Vapcomic & 4.0 & 4.3 & 4.2 \\
\hline
\end{tabular}

The insecticidal efficiency against 2 nd instar larvae of Tuta absoluta

\section{Laboratory evaluation}

The results of $\mathrm{LC}_{50}$ and $\mathrm{LC}_{90}$ (ppm) values, 95\% confidence limits, and other regression analysis factors of the traditional and non-traditional insecticides against the $2^{\text {nd }}$ instar larvae of T. absoluta are presented in Table 4. All tested non-traditional insecticides, except Actara, showed superior effect on T. absoluta. Emperor, Coragen, Radiant, and Vapcomic were the most efficient with $\mathrm{LC}_{50}$ values of $0.26,0.46,0.59$, and $0.60 \mathrm{ppm}$, respectively. The corresponding $\mathrm{LC}_{90}$ values were $1.66,1.82$, 4.84, and 8.09 ppm, respectively. In addition, Challenger and Imaxi revealed potent effect on T. Absoluta with $\mathrm{LC}_{50}$ of 24.07 and $40.23 \mathrm{ppm}$, respectively. On the other hand, Actara non-traditional insecticide exhibited very weak toxic effect $\left(\mathrm{LC}_{50}=2973.84\right)$ compared with the previous tested insecticides. It was lower than Emperor efficiency by 11000 folds. Pestban and Action phos traditional insecticides were more efficient than Actara with $\mathrm{LC}_{50}$ of 1051.19 and $2535.58 \mathrm{ppm}$, respectively. While Delta Plus traditional insecticide showed the least efficiency of the tested insecticides with $L_{50}$ value of $5515.04 \mathrm{ppm}$.

\section{Field evaluation}

Reduction percentages of T. absoluta infestation applied with the most potent insecticides (laboratory experiment) under field trials were revealed in Table 5. Emperor and Coragen insecticides were the most superior as they recorded 98.74 and $95.51 \%$ infestation reduction, respectively, followed by Radiant, Vapcomic, and Challenger as they were not significantly different with infestation reductions of $88.48,87.75$, and $84.89 \%$, respectively. The efficiency order of the tested insecticides was similar to data obtained under laboratory conditions. The percentage reduction in infestation had increased as time elapsed in all treatments.

\section{The biochemical effects}

The enzymatic and non-enzymatic antioxidants along with the photosynthetic pigments were determined to construe the biochemical changes induced by $T$. absoluta in tomato plants before and after treatments.

\section{Antioxidant enzymes}

Super oxide dismutase (SOD)

Data presented in Table 6 showed that, before spraying, the infestation of T. absoluta induced significant increase in the activity which ranged between 556 and $595 \mathrm{U} / \mathrm{g}$ f.w./h. All

Table 4 Toxicity of tested insecticides against the 2nd instar larvae of Tuta absoluta

\begin{tabular}{|c|c|c|c|c|c|c|c|c|}
\hline Insecticides & $\begin{array}{l}\mathrm{LC}_{50} \\
(\mathrm{mg} / \mathrm{L})^{\mathrm{a}}\end{array}$ & $\begin{array}{l}\text { 95\% confidence } \\
\text { limits (mg/L) }\end{array}$ & $\begin{array}{l}\mathrm{LC}_{90} \\
(\mathrm{mg} / \mathrm{L})\end{array}$ & $\begin{array}{l}\text { 95\% confidence } \\
\text { limits (mg/L) }\end{array}$ & Slope $\pm(S E)^{b}$ & Intercept $\pm(\mathrm{SE})^{\mathrm{C}}$ & $\left(x^{2}\right)^{d}$ & Toxicity index at $\mathrm{LC}_{50}$ \\
\hline \multicolumn{9}{|c|}{ Non-traditional insecticides } \\
\hline Actara & 2973.84 & $2218.90-3759.81$ & 14652.47 & 10184.08-27179.76 & $1.85 \pm 0.1$ & $6.43 \pm 0.38$ & 78.59 & 0.01 \\
\hline Challenger & 24.07 & $16.17-31.79$ & 164.56 & $106.42-367.95$ & $1.54 \pm 0.09$ & $2.12 \pm 0.16$ & 74.69 & 1.11 \\
\hline Coragen & 0.46 & $0.31-0.56$ & 1.82 & $1.49-2.40$ & $2.17 \pm 0.14$ & $0.72 \pm 0.04$ & 26.69 & 57.26 \\
\hline Emperor & 0.26 & $0.18-0.35$ & 1.66 & $1.06-3.87$ & $1.62 \pm 0.1$ & $0.924 \pm 0.05$ & 87.09 & 100.00 \\
\hline Imaxi & 40.23 & $28.34-56.83$ & 453.55 & 234.34-783.65 & $1.22 \pm 0.09$ & $1.955 \pm 0.16$ & 70.99 & 0.67 \\
\hline Radiant & 0.59 & $0.34-0.76$ & 4.84 & $3.64-6.54$ & $1.40 \pm 0.18$ & $0.322 \pm 0.04$ & 30.69 & 45.42 \\
\hline Vapcomic & 0.60 & $0.44-0.76$ & 8.09 & $5.64-13.41$ & $1.14 \pm 0.07$ & $0.25 \pm 0.03$ & 40.50 & 44.51 \\
\hline \multicolumn{9}{|c|}{ Traditional insecticides } \\
\hline Action Phos & 2535.58 & 1936.77-3167.62 & 10517.26 & 7489.07-18748.71 & $2.07 \pm 0.12$ & $7.06 \pm 0.44$ & 51.11 & 0.01 \\
\hline Delta Plus & 5515.04 & 4866.70-6193.58 & 13829.84 & $11277.14-19167.64$ & $3.21 \pm 0.20$ & $12.01 \pm 0.76$ & 34.14 & 0.005 \\
\hline Pestban & 1051.19 & $730.33-1356.92$ & 4348.89 & $3050.81-8448.13$ & $2.08 \pm 0.13$ & $6.28 \pm 0.43$ & 62.99 & 0.03 \\
\hline
\end{tabular}

${ }^{a}$ Concentration causing $50 \%$ mortality after $24 \mathrm{~h}$. of treatment; ${ }^{\mathrm{b}}$ Slope of concentration mortality regression line; ${ }^{\mathrm{C}}$ Intercept of regression line;

${ }^{\mathrm{d}}$ Chi square value 
Table 5 Reduction percentages of Tuta absoluta infestation treated with the most potent insecticides

\begin{tabular}{|c|c|c|c|c|c|c|c|c|c|c|c|c|}
\hline \multirow[t]{4}{*}{ Insecticides } & \multirow[t]{4}{*}{ Rate of application $\left(\mathrm{Cm}^{3} / \mathrm{F}\right)$} & \multicolumn{2}{|c|}{ Before-spray } & \multicolumn{8}{|c|}{ Reduction (\%) at indicated duration after application (mean \pm SD) } & \multirow{4}{*}{$\begin{array}{l}\text { Average } \\
\text { reduction \% }\end{array}$} \\
\hline & & & & \multirow{3}{*}{$\begin{array}{l}\text { Initial effect } \\
-1 \text { day } \\
\text { AL }\end{array}$} & \multicolumn{7}{|c|}{ Residual effect } & \\
\hline & & \multirow{2}{*}{$\begin{array}{l}\text { Alive } \\
\text { larvae } \\
\text { (AL) }\end{array}$} & \multirow{2}{*}{$\begin{array}{l}\% \\
\text { Infestation }\end{array}$} & & \multicolumn{2}{|l|}{3 days } & \multicolumn{2}{|l|}{5 days } & \multicolumn{3}{|l|}{7 days } & \\
\hline & & & & & $\% \mathrm{R}$ & $A L$ & $\% \mathrm{R}$ & $\mathrm{AL}$ & $\% \mathrm{R}$ & $A L$ & $\% R$ & \\
\hline Challenger & 410.0 & $\begin{array}{l}20.33 \\
\pm 3.2\end{array}$ & $\begin{array}{l}67.77 \pm \\
3.2\end{array}$ & $9.33 \pm 1.5^{b}$ & $\begin{array}{l}60.65 \\
\pm 1.5^{c}\end{array}$ & $\begin{array}{l}4.67 \pm \\
0.6^{b}\end{array}$ & $\begin{array}{l}78.67 \\
\pm 0.6^{b}\end{array}$ & $\begin{array}{l}3.67 \pm \\
0.6^{b}\end{array}$ & $\begin{array}{l}84.74 \\
\pm 0.5^{\mathrm{b}}\end{array}$ & $\begin{array}{l}1.67 \pm \\
0.6^{\mathrm{b}}\end{array}$ & $\begin{array}{l}91.27 \pm \\
0.5\end{array}$ & $84.89^{b}$ \\
\hline Coragen & 6.0 & $\begin{array}{l}18.33 \\
\pm 3.1\end{array}$ & $\begin{array}{l}61.10 \pm \\
3.1\end{array}$ & $\begin{array}{l}4.67 \pm \\
0.6^{\mathrm{cd}}\end{array}$ & $\begin{array}{l}78.18 \\
\pm 1.5^{b}\end{array}$ & $\begin{array}{l}1.67 \pm \\
1.5^{\mathrm{b}}\end{array}$ & $\begin{array}{l}91.55 \\
\pm 1.6^{a}\end{array}$ & $\begin{array}{l}0.67 \pm \\
1.2^{\text {cd }}\end{array}$ & $\begin{array}{l}96.92 \\
\pm 1.2^{\mathrm{a}}\end{array}$ & $\begin{array}{l}0.33 \pm \\
0.6^{\mathrm{b}}\end{array}$ & $\begin{array}{l}98.06 \pm \\
0.6\end{array}$ & $95.51^{a}$ \\
\hline Emperor & 200.0 & $\begin{array}{l}24.67 \\
\pm 7.8\end{array}$ & $\begin{array}{l}82.23 \pm \\
1.5\end{array}$ & $2.00 \pm 1.0^{d}$ & $\begin{array}{l}93.05 \\
\pm 1.0^{\mathrm{a}}\end{array}$ & $\begin{array}{l}1.00 \pm \\
1.0^{\mathrm{b}}\end{array}$ & $\begin{array}{l}96.23 \\
\pm 1.0^{\mathrm{a}}\end{array}$ & $\begin{array}{l}0.00 \pm \\
0.0^{d}\end{array}$ & $\begin{array}{l}100.0 \\
\pm 0.0^{\mathrm{a}}\end{array}$ & $\begin{array}{l}0.00 \pm \\
0.0^{b}\end{array}$ & $\begin{array}{l}100.00 \pm \\
0.0\end{array}$ & $98.74^{a}$ \\
\hline Radiant & 25.0 & $\begin{array}{l}19.33 \\
\pm 2.1\end{array}$ & $\begin{array}{l}64.43 \pm \\
2.1\end{array}$ & $\begin{array}{l}7.67 \pm \\
1.5^{\mathrm{bc}} \pm\end{array}$ & $\begin{array}{l}66.00 \\
\pm 1.6^{c}\end{array}$ & $\begin{array}{l}4.00 \pm \\
1.0^{b}\end{array}$ & $\begin{array}{l}80.77 \\
\pm 1.0^{b}\end{array}$ & $\begin{array}{l}2.67 \pm \\
0.6^{b c} \pm\end{array}$ & $\begin{array}{l}88.33 \\
\pm 0.5^{b}\end{array}$ & $\begin{array}{l}0.67 \pm \\
0.6^{\mathrm{b}}\end{array}$ & $\begin{array}{l}96.33 \pm \\
0.5\end{array}$ & $88.48^{\mathrm{b}}$ \\
\hline Vapcomic & 270.0 & $\begin{array}{l}21.33 \\
\pm 7.8\end{array}$ & $\begin{array}{l}71.10 \pm 7 \\
8\end{array}$ & $\begin{array}{l}5.00 \pm \\
2.0^{c d}\end{array}$ & $\begin{array}{l}79.91 \\
\pm 2.0^{b}\end{array}$ & $\begin{array}{l}4.33 \pm \\
0.6^{\mathrm{b}}\end{array}$ & $\begin{array}{l}81.12 \\
\pm 0.5^{b}\end{array}$ & $\begin{array}{l}3.67 \pm \\
1.2^{\mathrm{b}} \pm\end{array}$ & $\begin{array}{l}85.46 \\
\pm 1.1^{\mathrm{b}}\end{array}$ & $\begin{array}{l}0.67 \pm \\
1.2^{\mathrm{b}}\end{array}$ & $\begin{array}{l}96.67 \pm \\
0.6\end{array}$ & $87.75^{b}$ \\
\hline Control & - & $\begin{array}{l}22.00 \\
\pm 3.0\end{array}$ & $\begin{array}{l}73.33 \pm \\
3.0\end{array}$ & $\begin{array}{l}25.67 \pm \\
2.5^{\mathrm{a}}\end{array}$ & - & $\begin{array}{l}23.67 \\
\pm 7.8^{\mathrm{a}}\end{array}$ & - & $\begin{array}{l}26.00 \\
\pm 3.0^{a}\end{array}$ & - & $\begin{array}{l}20.67 \\
\pm 4.04^{\mathrm{a}}\end{array}$ & - & - \\
\hline LSD $_{0.05}$ & & NS & NS & 3.11 & 11.93 & 5.73 & 8.56 & 2.55 & 6.38 & 3.14 & NS & 5.28 \\
\hline
\end{tabular}

(\%R= Reduction percentages of infestation; L.S.D0.05 least significant difference at 0.05 level of probability; N.S not significant difference at 0.05 level of probability; Means accompanied by the same letter in a column are not significantly different at 0.05 level of probability. $\mathrm{AL}=\mathrm{Alive}$ Larvae)

the examined insecticides significantly reduced SOD enzyme activity relative to control (invaded plants) at all measured durations. The treated plants enzyme activity was declined gradually with time elapsed, till it reached the minimum activity level at 7 days after treatment (DAT). Emperor and Coragen caused the least enzyme activity, where they reached 336 and $345 \mathrm{U} / \mathrm{g}$ f.w./h, respectively, followed by Radiant and Vapcomic (380 and 384) then Challenger (401.33) compared with control (588) at the same period. These findings were in agreement with the obtained results in the field, where it shows high efficiency in reducing the insect infestation with descending order (Emperor $>$ Coragen $>$ Vapcomic $>$ Radiant $>$ Challenger).

\section{Catalase enzyme (CAT)}

The influence of the examined insecticides on CAT (Table 6) was matched with SOD, where the actions of the tested insecticides were significantly different relative to the control over the durations studied. All applications significantly diminished CAT enzyme activity relative to the control (infested plants) which remained virtually unchanged at all various testing intervals. The CAT activity decreased gradually with time elapsed. The least enzyme activity was observed by Emperor (16.33, 14.15, and 11.43) and Coragen (18.51, 14.70, and 13.61 $\mathrm{U} / \mathrm{g}$ f.w./h), respectively after 3,5 , and 7 DAT.

\section{Polyphenol oxidase (PPO)}

Data given in Table 6 clarified that all treatments significantly reduced PPO enzyme activity relative to the control (invaded plants). The maximum activity of PPO was recorded before spray which ranged from 41.65 to 46.80
U/g f.w./h. Emperor, Coragen, Vapcomic, and Radiant recorded the least enzyme activity at $7 \mathrm{DAT}$, where they ranged from 8.48 to $11.12 \mathrm{U} / \mathrm{g}$ f.w./h. On the other hand, Challenger recorded $20.80 \mathrm{U} / \mathrm{g}$ f.w./h compared to the control of 71.76 .

\section{Glutathione-S-transferase (GST)}

The activity of GST enzyme was like that of PPO, where GST enzyme activity was increased in the control plants which indeed a result of insect infestation, while it was decreased of the treated plants with time passed (Table 6). Emperor, Coragen, Radiant, and Vapcomic showed the least enzyme activities which were 37.49 to $42.37 \mathrm{U} / \mathrm{ml} / \mathrm{g}$ tissue at 7 DAT, followed by Challenger (50.24). On the other hand, the control revealed the highest enzyme activity (114.92 U/ml/g tissue) at the same duration.

\section{Non-enzyme antioxidant \\ Total phenol contents}

Data in Table 7 pointed out that the infestation by $T$. absoluta (untreated plants) induced a significant increase in total phenol contents which ranged among 121.02 to $126.14 \mathrm{mg} / \mathrm{g}$ f.w. The total phenol contents of treated plants decreased gradually with time elapsed until it reached its minimal level at 7 DAT. There were no significant variations of total phenol contents between all evaluated insecticides at 7 DAT as they ranged from 59.71 to $62.36 \mathrm{mg} / \mathrm{g}$ f.w. except Challenger which was 70.31 relative to the control (121.19) at the same period. 
Table 6 Effect of the tested insecticides on certain antioxidant enzymes of tomato plants

\begin{tabular}{|c|c|c|c|c|c|c|}
\hline \multirow{2}{*}{$\begin{array}{l}\text { Enzyme activity } \pm S D \\
(\mathrm{U} / \mathrm{g} \text { fresh weight/h) }\end{array}$} & \multirow[t]{2}{*}{ Insecticides } & \multicolumn{5}{|c|}{ Days after treatment } \\
\hline & & Before spray & One & Three & Five & Seven \\
\hline \multirow[t]{7}{*}{ Super oxide dismutase } & Challenger & $582.00 \pm 17.0$ & $468.67 \pm 29.7^{b}$ & $444.00 \pm 24.0^{b}$ & $426.67 \pm 29.7^{b}$ & $401.33 \pm 5.7^{b}$ \\
\hline & Coragen & $595.0 \pm 24.0$ & $433.00 \pm 7.10^{c}$ & $400.0 \pm 28.3^{\mathrm{cd}}$ & $362.0 \pm 31.1^{c}$ & $345.0 \pm 18.4^{d}$ \\
\hline & Emperor & $576.0 \pm 39.6$ & $412.20 \pm 33.9^{c}$ & $379.0 \pm 18.4^{d}$ & $359.0 \pm 15.6^{c}$ & $336.0 \pm 11.3^{d}$ \\
\hline & Radiant & $584.0 \pm 25.5$ & $468.00 \pm 14.1^{b}$ & $458.0 \pm 11.3^{b}$ & $410.0 \pm 17.0^{b}$ & $380.0 \pm 11.3^{c}$ \\
\hline & Vapcomic & $556.0 \pm 11.3$ & $426.00 \pm 5.70^{c}$ & $417.0 \pm 4.2^{c}$ & $401.0 \pm 26.9^{b}$ & $384.0 \pm 8.5^{c}$ \\
\hline & Control & $582.0 \pm 20.0$ & $554.00 \pm 17.6^{a}$ & $562.0 \pm 42.5^{a}$ & $582.0 \pm 32.3^{\mathrm{a}}$ & $588.0 \pm 22.7^{\mathrm{a}}$ \\
\hline & $\mathrm{LSD}_{0.05}$ & NS & 24.72 & 22.19 & 32.15 & 16.41 \\
\hline \multirow[t]{7}{*}{ Catalase } & Challenger & $37.31 \pm 2.63$ & $29.87 \pm 2.45^{b}$ & $25.84 \pm 2.35^{b}$ & $19.59 \pm 2.51^{\mathrm{b}}$ & $19.19 \pm 2.74^{b}$ \\
\hline & Coragen & $34.30 \pm 0.79$ & $24.50 \pm 2.72^{c}$ & $18.51 \pm 1.09^{c}$ & $14.70 \pm 0.54^{c}$ & $13.61 \pm 0.54^{d}$ \\
\hline & Emperor & $36.47 \pm 1.63$ & $23.41 \pm 1.63^{c}$ & $16.33 \pm 1.09^{c}$ & $14.15 \pm 1.08^{c}$ & $11.43 \pm 0.54^{d}$ \\
\hline & Radiant & $38.11 \pm 1.09$ & $28.31 \pm 2.18^{c}$ & $25.04 \pm 2.18^{b}$ & $19.60 \pm 1.09^{b}$ & $16.33 \pm 1.09^{b c}$ \\
\hline & Vapcomic & $37.56 \pm 1.63$ & $25.59 \pm 2.65^{c}$ & $23.41 \pm 2.72^{b}$ & $19.05 \pm 1.64^{b}$ & $16.88 \pm 1.63^{c}$ \\
\hline & Control & $37.02 \pm 2.18$ & $40.83 \pm 0.77^{\mathrm{a}}$ & $37.56 \pm 0.77^{\mathrm{a}}$ & $34.84 \pm 3.08^{\mathrm{a}}$ & $39.20 \pm 1.54^{a}$ \\
\hline & $\mathrm{LSD}_{0.05}$ & NS & 3.56 & 3.48 & 3.07 & 2.63 \\
\hline \multirow[t]{7}{*}{ Polyphenol oxidase } & Challenger & $41.65 \pm 1.47$ & $34.24 \pm 10.3^{b}$ & $31.73 \pm 22.4^{b}$ & $23.25 \pm 1.7^{b}$ & $20.80 \pm 6.8^{b}$ \\
\hline & Coragen & $46.80 \pm 7.4$ & $29.52 \pm 0.6^{b c}$ & $22.08 \pm 6.6^{b}$ & $13.52 \pm 0.6^{c}$ & $9.12 \pm 0.5^{c}$ \\
\hline & Emperor & $45.60 \pm 7.0$ & $27.76 \pm 0.6^{c}$ & $21.12 \pm 2.0^{\mathrm{b}}$ & $10.32 \pm 2.4^{c}$ & $8.48 \pm 1.8^{c}$ \\
\hline & Radiant & $46.80 \pm 1.5$ & $34.64 \pm 1.7^{\mathrm{b}}$ & $28.56 \pm 1.9^{b}$ & $20.08 \pm 1.2^{b}$ & $11.12 \pm 0.8^{c}$ \\
\hline & Vapcomic & $46.80 \pm 5.5$ & $32.32 \pm 2.7^{b c}$ & $26.08 \pm 0.9^{b}$ & $20.64 \pm 7.0^{b}$ & $11.04 \pm 1.6^{c}$ \\
\hline & Control & $42.72 \pm 2.9$ & $51.04 \pm 1.6^{\mathrm{a}}$ & $68.64 \pm 1.1^{\mathrm{a}}$ & $71.36 \pm 5.7^{\mathrm{a}}$ & $71.76 \pm 7.8^{\mathrm{a}}$ \\
\hline & $\mathrm{LSD}_{0.05}$ & NS & 5.85 & 18.52 & 5.86 & 7.64 \\
\hline \multirow[t]{7}{*}{ Glutathione-S-transferase } & Challenger & $79.99 \pm 5.1^{\mathrm{bc}}$ & $63.74 \pm 2.0^{b}$ & $58.61 \pm 10.8^{b}$ & $54.12 \pm 68^{b}$ & $50.24 \pm 8.2^{b}$ \\
\hline & Coragen & $76.86 \pm 2.2^{c}$ & $56.80 \pm 1.3^{c}$ & $47.24 \pm 0.7^{c}$ & $41.24 \pm 3.0^{c}$ & $38.06 \pm 0.2^{c}$ \\
\hline & Emperor & $76.86 \pm 4.5^{c}$ & $50.99 \pm 1.9^{d}$ & $45.55 \pm 0.9^{c}$ & $40.12 \pm 2.2^{c}$ & $37.49 \pm 2.6^{c}$ \\
\hline & Radiant & $78.55 \pm 4.7^{\mathrm{bc}}$ & $62.43 \pm 2.1^{b}$ & $52.49 \pm 0.4^{\mathrm{bc}}$ & $49.87 \pm 1.9^{b}$ & $42.18 \pm 2.1^{c}$ \\
\hline & Vapcomic & $83.99 \pm 1.9^{b}$ & $56.05 \pm 2.4^{c}$ & $52.30 \pm 2.8^{b c}$ & $50.24 \pm 2.2^{b}$ & $42.37 \pm 1.9^{c}$ \\
\hline & Control & $93.73 \pm 1.5^{\mathrm{a}}$ & $93.73 \pm 3.4^{\mathrm{a}}$ & $110.79 \pm 0.8^{a}$ & $112.48 \pm 0.5^{a}$ & $114.92 \pm 1.9^{a}$ \\
\hline & $\mathrm{LSD}_{0.05}$ & 6.46 & 4.02 & 8.16 & 6.04 & 6.63 \\
\hline
\end{tabular}

L.S.D. $D_{0.05}$ least significant difference at 0.05 level of probability; N.S not significant difference at 0.05 level of probability; Means accompanied by the same letter in a column are not significantly different at 0.05 level of probability

Table 7 Effect of the tested insecticides on total phenol contents of tomato plants

\begin{tabular}{|c|c|c|c|c|c|}
\hline \multirow[t]{2}{*}{ Insecticides } & \multicolumn{5}{|c|}{ Total phenol (mg/g fresh weight) at indicated days after treatment (mean \pm SD) } \\
\hline & Before spray & One & Three & Five & Seven \\
\hline Challenger & $100.11 \pm 11.56$ & $88.92 \pm 7.8^{b}$ & $81.74 \pm 3.68^{b}$ & $78.91 \pm 3.81^{b}$ & $70.31 \pm 2.89^{b}$ \\
\hline Coragen & $104.94 \pm 4.0$ & $76.32 \pm 3.1^{c}$ & $71.55 \pm 4.7^{\mathrm{c}}$ & $66.96 \pm 2.2^{\text {de }}$ & $61.13 \pm 2.0^{c}$ \\
\hline Emperor & $111.83 \pm 4.20$ & $76.67 \pm 2.5^{c}$ & $67.84 \pm 2.0^{c}$ & $62.89 \pm 2.2^{\mathrm{e}}$ & $59.71 \pm 1.5^{c}$ \\
\hline Radiant & $117.13 \pm 2.3$ & $89.92 \pm 9.0^{b}$ & $79.85 \pm 3.2^{b}$ & $69.78 \pm 3.0^{c d}$ & $61.48 \pm 2.5^{c}$ \\
\hline Vapcomic & $104.94 \pm 4.0$ & $86.74 \pm 3.2^{b c}$ & $78.09 \pm 4.5^{b}$ & $74.91 \pm 7.5^{b c}$ & $62.36 \pm 2.2^{c}$ \\
\hline Control & $122.43 \pm 4.42$ & $124.20 \pm 8.3^{a}$ & $126.14 \pm 1.8^{\mathrm{a}}$ & $121.02 \pm 3.0^{a}$ & $121.19 \pm 6.4^{\mathrm{a}}$ \\
\hline $\mathrm{LSD}_{0.05}$ & NS & 10.87 & 5.14 & 5.84 & 5.69 \\
\hline
\end{tabular}




\section{Photosynthetic pigments}

Results in Table 8 clarified the impact of the tested insecticides on photosynthetic pigments (chlorophyll a, b, and carotene contents) in tomato leaves at different time intervals. The treatments caused an increase of the photosynthetic pigments with time elapsed. The maximum level of the tested pigments was achieved at 7 DAT. Emperor and Coragen achieved the highest content of the total pigments at all the tested durations. The two tested insecticides gave 9.44 and $9.18 \mathrm{mg} / \mathrm{g}$ f.w. of chlorophyll a, respectively, at 7 DAT. Chlorophyll b and carotene contents were increased in all treated plants at 5 and 7 DAT, in addition, they were not significantly different compared with the control (infested plants).

\section{Economics and marketable yield}

The effect of the assessed insecticides on tomato yield was provided in Table 9. The results indicated that all the treated insecticides significantly increased tomato yield. Emperor and Coragen recorded the maximum yield of 30.7 and 29.9 tons/fed., respectively, while there were no significant differences of tomato yield between the other tested insecticides (Challenger, Radiant, and Vapcomic) which ranged from 26.4 to 27.5 tons/fed. compared with the control (10.4 tons/fed). The data pertaining to the increase of yield were similar to the results of tomato yield, where the highest increases of yield (195.2\%) and (187.5\%) were obtained by Emperor and Coragen, respectively. These two insecticides investigated the highest additional income over control that estimated by 29983 and 28801 pounds/fed., respectively, followed by Radiant of 25257 pounds/fed. (Table 9).The highest net profit per feddan occurred when tomato plants treated with Emperor and Coragen which achieved $\sim 34882.9$ and 31881.3 pounds/fed., respectively, whereas, the other examined insecticides were at par with each other, as the net profit ranged from 28485 to 29456 pounds/fed. On the other hand, the untreated control yielded 9799.0 pounds/fed (Table 9). In addition, the best incremental cost-benefit ratio (ICBR) of 1:7.12 was obtained by Emperor. However, there were slight changes of ICBR between the other tested insecticides, where it ranged between 1: 4.75 and 1: 5.75. The minimum ICBR was recorded by Coragen.

\section{Discussion}

The potency of the tested insecticides on T. absoluta along with their biochemical effects on tomato plants was evaluated. Data of the physical and chemical properties of the examined insecticides pointed out that the creaming volumes layer were $0 \mathrm{ml}$, except Action Phos and Pestban, where the separating layers surpassed $2 \mathrm{ml}$, the level of cream layer, if any, should not surpass $2 \mathrm{ml}$ (WHO 1979). Moreover, the foam levels of the insecticides that achieved success in the emulsion stability did not override $5 \mathrm{ml}$, while that failed the emulsion stability and failed the foam formation as well; the volume of the foam layer should not exceed $5 \mathrm{ml}$ (WHO 1979). The $\mathrm{pH}$ of the estimated insecticides was ranged from four to seven, with the exception of Actara and Action Phos as they were above seven. Our results were consistent with Halcomb (2012) and Abdel-Aziz et al. (2018) who stated that the safe $\mathrm{pH}$ of a pesticide solution ranges from 4.5 to 7.0. Many pesticides react chemically in the presence of water at $\mathrm{pH}$ above seven (alkaline hydrolysis), which reduces the effectiveness of pesticides (Fishel 2002). The PH also affects the absorption of spray solutions through the cuticle and leaf surfaces across the phytotoxicity (Abdel-Aziz et al. 2018). The findings of the experiments exhibited above clarified that Actra failed the chemical and physical properties of the non-traditional insecticides and Action Phos and Pestban of the conventional insecticides.

The current research revealed that the non-traditional insecticides, except Actara, possessed excellent insecticidal efficacy against $T$. absoluta. Our results were in harmony with Roditakis et al. (2013) who found that emamectin benzoate, chlorantraniliprole, and spinosad showed superior efficacy against $T$. absoluta with $\mathrm{LC}_{50}$ that ranged from 0.03 to $0.53 \mathrm{ppm}$; on the other hand, the tested populations exhibited high tolerance to chlorpyriphos and cypermethrin ( $\mathrm{LC}_{50}$ ranged from 475 to 2038 ppm). Roby and Hussein (2019) reported that emamectin benzoate exhibited high toxic effect against $T$. absoluta. In addition, Simmons et al. (2018) mentioned that the efficacy of spinosad and emamectin benzoate on T. absoluta was high (more than $90 \%$ mortality). In the same trend, Sridhar et al. (2016) evaluated 11 insecticides against $T$. absoluta. The most effective insecticides against the pest were spinetoram, cyantraniliprole, and spinosad. The poor efficacy of Actra at the present study may be due to the high $\mathrm{pH}$ value, where it affects the potency of the active ingredient and the penetration of the insecticide. Our data matched with Silva et al. (2015) who mentioned that all pyrethroids assessed exhibited no efficacy against all $T$. absoluta populations. Guedes and Picanço (2012) stated that the organophosphates and the pyrethroids were the insecticides initially available against $T$. absoluta until the 1990s, but the detection of resistance to these insecticides led to the registration and use of new active substances. Moreover, the current research clearly revealed that the insecticides that failed the physical and chemical properties exhibited low efficiency against the tested insect.

Insect infestation causes biotic stress on plants which stimulates producing the reactive oxygen species involving superoxide and hydrogen peroxide, thereby increasing the intrinsic antioxidant enzyme activity, like superoxide 
Table 8 Effect of the tested insecticides on chlorophyll a, b, carotene content, and total pigments of tomato leaves at different intervals of application

\begin{tabular}{|c|c|c|c|c|}
\hline Treatments & $\begin{array}{l}\text { Chlorophyll (a) } \pm \text { SD } \\
\text { (mg/g f.w.t) }\end{array}$ & $\begin{array}{l}\text { Chlorophyll (b) } \pm \text { SD } \\
\text { (mg/g f.w.) }\end{array}$ & $\begin{array}{l}\text { Carotene content } \pm \text { SD } \\
(\mathrm{mg} / \mathrm{g} \text { f.w.) }\end{array}$ & $\begin{array}{l}\text { Total pigments } \pm \text { SD } \\
\text { (mg/g f.w.) }\end{array}$ \\
\hline \multicolumn{5}{|l|}{ Before spray } \\
\hline Challenger & $6.48 \pm 0.29$ & $4.50 \pm 0.30$ & $4.91 \pm 0.82$ & $15.89 \pm 0.85$ \\
\hline Coragen & $6.41 \pm 0.13$ & $4.64 \pm 0.49$ & $5.07 \pm 1.10$ & $16.11 \pm 0.47$ \\
\hline Emperor & $6.52 \pm 0.43$ & $4.69 \pm 0.43$ & $5.04 \pm 0.32$ & $16.26 \pm 0.14$ \\
\hline Radiant & $6.54 \pm 0.43$ & $4.58 \pm 0.50$ & $5.08 \pm 2.51$ & $16.20 \pm 2.47$ \\
\hline Vapcomic & $6.44 \pm 0.38$ & $4.75 \pm 0.40$ & $4.93 \pm 0.64$ & $16.11 \pm 0.48$ \\
\hline Control & $5.88 \pm 0.12$ & $4.69 \pm 0.68$ & $4.93 \pm 0.88$ & $15.49 \pm 0.62$ \\
\hline $\mathrm{LSD}_{0.05}$ & NS & NS & NS & NS \\
\hline \multicolumn{5}{|c|}{ After 1 day of application } \\
\hline Challenger & $6.70 \pm 0.20^{\mathrm{a}}$ & $4.61 \pm 0.27$ & $5.31 \pm 0.87$ & $16.63 \pm 0.99^{a}$ \\
\hline Coragen & $6.78 \pm 0.07^{a}$ & $4.85 \pm 0.18$ & $5.31 \pm 0.67$ & $16.94 \pm 0.59^{a}$ \\
\hline Emperor & $6.91 \pm 0.48^{\mathrm{a}}$ & $4.83 \pm 0.44$ & $5.12 \pm 0.45$ & $16.86 \pm 0.48^{\mathrm{a}}$ \\
\hline Radiant & $6.79 \pm 0.18^{a}$ & $4.71 \pm 0.26$ & $5.28 \pm 0.25$ & $16.78 \pm 0.25^{a}$ \\
\hline Vapcomic & $6.74 \pm 0.06^{\mathrm{a}}$ & $4.86 \pm 0.25$ & $5.13 \pm 0.18$ & $16.78 \pm 0.27^{a}$ \\
\hline Control & $5.62 \pm 0.02^{b}$ & $4.38 \pm 0.35$ & $4.41 \pm 0.46$ & $14.42 \pm 0.46^{b}$ \\
\hline $\mathrm{LSD}_{0.05}$ & 0.41 & NS & Ns & 0.91 \\
\hline \multicolumn{5}{|c|}{ After 3 days of application } \\
\hline Challenger & $7.61 \pm 0.29^{c}$ & $5.20 \pm 0.64$ & $5.37 \pm 0.62$ & $17.23 \pm 0.19^{c}$ \\
\hline Coragen & $8.20 \pm 0.09^{\mathrm{ab}}$ & $4.93 \pm 0.60$ & $5.45 \pm 0.66$ & $18.57 \pm 0.23^{\mathrm{ab}}$ \\
\hline Emperor & $8.42 \pm 0.20^{\mathrm{a}}$ & $4.95 \pm 0.07$ & $5.45 \pm 0.56$ & $18.81 \pm 0.73^{\mathrm{a}}$ \\
\hline Radiant & $7.89 \pm 0.28^{b c}$ & $4.70 \pm 0.75$ & $5.25 \pm 0.44$ & $17.84 \pm 0.20^{\mathrm{bc}}$ \\
\hline Vapcomic & $7.93 \pm 0.19^{b c}$ & $4.91 \pm 0.23$ & $5.21 \pm 0.15$ & $17.86 \pm 0.36^{\mathrm{bc}}$ \\
\hline Control & $5.67 \pm 0.15^{d}$ & $4.36 \pm 0.37$ & $4.42 \pm 0.39$ & $14.45 \pm 0.45^{d}$ \\
\hline $\mathrm{LSD}_{0.05}$ & 0.39 & NS & NS & 0.85 \\
\hline \multicolumn{5}{|c|}{ After 5 days of application } \\
\hline Challenger & $7.98 \pm 0.17^{b}$ & $5.88 \pm 0.62^{a}$ & $5.70 \pm 0.94^{\mathrm{a}}$ & $19.56 \pm 0.70^{b}$ \\
\hline Coragen & $8.58 \pm 0.16^{\mathrm{a}}$ & $6.40 \pm 0.49^{a}$ & $6.12 \pm 0.36^{a}$ & $21.09 \pm 024^{a}$ \\
\hline Emperor & $8.72 \pm 0.07^{\mathrm{a}}$ & $6.41 \pm 0.87^{a}$ & $6.19 \pm 0.85^{a}$ & $21.33 \pm 0.13^{\mathrm{a}}$ \\
\hline Radiant & $8.15 \pm 0.07^{b}$ & $6.10 \pm 0.40^{a}$ & $5.86 \pm 0.43^{\mathrm{a}}$ & $20.10 \pm 0.23^{b}$ \\
\hline Vapcomic & $8.15 \pm 0.12^{b}$ & $6.17 \pm 0.49^{a}$ & $5.87 \pm 0.52^{\mathrm{a}}$ & $20.17 \pm 0.36^{b}$ \\
\hline Control & $5.44 \pm 0.34^{c}$ & $4.45 \pm 0.44^{b}$ & $4.19 \pm 0.24^{b}$ & $14.07 \pm 0.16^{c}$ \\
\hline $\mathrm{LSD}_{0.05}$ & 0.32 & 1.02 & 1.09 & 0.63 \\
\hline \multicolumn{5}{|c|}{ After 7 days of application } \\
\hline Challenger & $8.51 \pm 0.30^{c}$ & $6.07 \pm 0.60^{\mathrm{a}}$ & $5.95 \pm 0.67^{\mathrm{a}}$ & $20.53 \pm 0.75^{c}$ \\
\hline Coragen & $9.18 \pm 0.07^{\mathrm{ab}}$ & $6.75 \pm 0.40^{\mathrm{a}}$ & $6.30 \pm 0.24^{a}$ & $22.23 \pm 0.39^{\mathrm{ab}}$ \\
\hline Emperor & $9.44 \pm 0.30^{\mathrm{a}}$ & $6.85 \pm 0.86^{\mathrm{a}}$ & $6.34 \pm 0.70^{a}$ & $22.63 \pm 0.15^{a}$ \\
\hline Radiant & $8.84 \pm 0.26^{\mathrm{bc}}$ & $6.29 \pm 0.60^{a}$ & $6.12 \pm 0.90^{a}$ & $21.25 \pm 0.72^{b c}$ \\
\hline Vapcomic & $8.94 \pm 0.41^{\mathrm{abc}}$ & $6.25 \pm 0.92^{\mathrm{a}}$ & $6.07 \pm 0.77^{a}$ & $21.26 \pm 0.55^{b c}$ \\
\hline Control & $5.45 \pm 0.33^{d}$ & $4.32 \pm 0.33^{b}$ & $4.24 \pm 0.75^{b}$ & $14.00 \pm 0.77^{d}$ \\
\hline $\mathrm{LSD}_{0.05}$ & 0.53 & 1.17 & 1.25 & 1.07 \\
\hline
\end{tabular}

L.S.D $D_{0.05}$ least significant difference at 0.05 level of probability; N.S not significant difference at 0.05 level of probability; Means accompanied by the same letter in a column are not significantly different at 0.05 level of probability 
Table 9 Effect of the tested insecticides on the marketable yield of tomato plants

\begin{tabular}{|c|c|c|c|c|c|c|c|}
\hline Insecticides & $\begin{array}{l}\text { Tomato yield } \pm \text { SD } \\
\text { (ton/fed.) }\end{array}$ & $\begin{array}{l}\text { Increase of yield } \pm \\
\text { SD (\%) }\end{array}$ & $\begin{array}{l}\text { Insecticide cost } \\
\text { (pound/fed.) }\end{array}$ & $\begin{array}{l}\text { Total cost } \\
\text { (pound/fed.) }\end{array}$ & $\begin{array}{l}\text { Additional income } \\
\text { over control } \pm \text { SD } \\
\text { (pound/fed.) }\end{array}$ & $\begin{array}{l}\text { Net profit } \\
\text { (pound/fed.) } \pm S D\end{array}$ & ICBR \\
\hline Challenger & $26.4 \pm 1.4^{b}$ & $153.8 \pm 13.6^{c}$ & 4950 & 10511 & $23632 \pm 2074^{c}$ & $28481.8 \pm 2074^{b}$ & $\begin{array}{l}1: \\
5.75\end{array}$ \\
\hline Coragen & $29.9 \pm 1.4^{\mathrm{a}}$ & $187.5 \pm 13.6^{\mathrm{ab}}$ & 6720 & 12281 & $28801 \pm 2094^{\mathrm{ab}}$ & $31881.3 \pm 2094^{\mathrm{ab}}$ & $\begin{array}{l}1: \\
4.75\end{array}$ \\
\hline Emperor & $30.7 \pm 1.1^{\mathrm{a}}$ & $195.2 \pm 10.1^{a}$ & 4900 & 10461 & $29983 \pm 1556^{a}$ & $34882.9 \pm 1556^{a}$ & $\begin{array}{l}1: \\
7.12\end{array}$ \\
\hline Radiant & $27.5 \pm 1.3^{b}$ & $164.4 \pm 11.9^{b c}$ & 5600 & 11161 & $25257 \pm 1844^{b c}$ & $29456.5 \pm 1844^{b}$ & $\begin{array}{l}1: \\
5.26\end{array}$ \\
\hline Vapcomic & $27.3 \pm 1.6^{b}$ & $162.5 \pm 15.1^{c}$ & 5320 & 10881 & $24961 \pm 2321^{c}$ & $29441.1 \pm 2321^{b}$ & $\begin{array}{l}1: \\
5.53\end{array}$ \\
\hline Control & $10.4 \pm 1.2^{c}$ & - & - & 5561 & - & $9799.0 \pm 1858^{c}$ & - \\
\hline $\mathrm{LSD}_{0.05}$ & 2.38 & 23.59 & & & 3636.97 & 3505.72 & \\
\hline
\end{tabular}

L.S.D 0.05 least significant difference at 0.05 level of probability; N.S not significant difference at 0.05 level of probability; Means accompanied by the same letter in a column are not significantly different at 0.05 level of probability; ICBR incremental cost-benefit ratio

dismutase, catalase, glutathione s-transferase, and polyphenol oxidase compared with the un-infested plants to protect the infested ones from these harmful insects (Mahmoud et al. 2004). The control of insect infestation drives to a reduction in plant stress, thus reducing the activity of antioxidant enzymes. This is coinciding with the obtained results which indicated that all plants treated with the examined compounds significantly reduced SOD enzyme activity compared to the control (infested plants) all examined intervals. Also, CAT is an important component of the oxygen-scavenging regimes that scavenges the harmful and unsteady ROS and turns them into minimal toxic and more steady ingredients such as $\mathrm{O}_{2}$ and $\mathrm{H}_{2} \mathrm{O}$ (Afiyanti and Chen 2014; Khattab and Khattab 2005). The enzyme PPO plays an essential role in plant defense against insect herbivore as an anti-nutritional enzyme; it reduces the food quality and might also be toxic to the larvae (Constabel and Barbehenn 2008; Mahanil et al. 2008). This enzyme catalyses the oxidation of phenolic compounds into quinones, which can bind to amino acids. Generally, the PPO enzyme activity data showed that the infested plants induced a significant increase in the activity.

The proposed function of GST involves the detoxification peroxides to prevent continuing cell death caused by free radicals produced (Shahrtash 2013). The induction of GST enzyme is correlated with increasing concentrations of hydrogen peroxide $\left(\mathrm{H}_{2} \mathrm{O}_{2}\right)$, which are the most important reactive oxygen species, and they rapidly accumulate in response to biotic stresses such as insect feeding (Venisse et al. 2001). GSTs may detoxify peroxides which, if not reduced, will convert to cytotoxic derivatives that can damage plant cells (Dean et al. 2005).

Data of the current research revealed that the increase of the phenolic contents of the infested plants was accompanied by an increase in PPO activity. Thipyapong et al. (1995) and Sammour et al. (2018) reported that the total phenols act as substrates of the antioxidant enzyme PPO, which oxidize phenolic compounds into quinones. Moreover, phenolic compounds induced in plants are either directly toxic to insects or produce toxic secondary metabolites and activates the defensive enzymes (Bhonwong et al. 2009; Maffei et al. 2007).

Feeding herbivorous insects causes biochemical and physiological changes in host plants that affect their vital operations, including photosynthesis (Gomez et al. 2004). The chlorophyll content in plant cells is one important factor for the relationship between host plants and insects. Changes in chlorophyll levels during plant growth and nutrient deficiency are caused by high stress levels, which include biotic stress factors caused by insect feeding (Goławska et al. 2010; Sammour et al. 2018). Our findings were conformed with Aldea et al. (2006) and Tang et al. (2005) who stated that plant damaged by herbivorous insects resulted in a diminish in total pigments. The irregular mines on the tomato leaf surface caused by $T$. absolute, diminishing the photosynthetic capacity of the plant and potentially decreasing the plant's ability to defend itself from other harmful agents (Biondi et al. 2018).

It can be concluded from this study that there is an inverse relationship between the content of the photosynthetic pigments and the antioxidant enzymes activity whereas the insect infestation cause suppression in photosynthetic pigments while causing an increase of the defensive compounds (antioxidant enzymes) (Gog et al. 2005; Nabity et al. 2008).

In this study, Emperor and Coragen investigated the highest tomato yield. This result was in correspondence with the laboratory and field findings, as these insecticides were the most efficient against $T$ absoluta. On closer examination of the data, the trend of higher insect 
control shows higher yields. Aktar et al. (2009) reported that a considerable economic loss would happen without insecticide use and significant increases in yield resulted from insecticide use. Our results were in conformity with Ayalew (2015) who screened locally available insecticides on T. absoluta, and data elucidated that Coragen possessed the highest marketable and total yield of 15.3 and $27.1 \mathrm{t} / \mathrm{ha}$, respectively. The highest additional income over control and the net profit in the current research resulted from Emperor and Coragen treatments. The incremental cost-benefit ratio (ICBR) is an indicator of the relative economic performance of the treatments (Amoabeng et al. 2014). ICBR provided by each treatment is greatly affected by the insecticide price. The study findings showed that Coragen had a higher yield but lower ICBR because its price was higher than the other examined insecticides. The current research was in line with Sreekanth et al. (2014) who reported that the highest ICBR were recorded by chlorantraniliprole followed by indoxacarb, abamectin, and spinetoram.

\section{Conclusions}

The present findings revealed that Emperor and Coragen were the most superior insecticides against $T$. absoluta followed by Radiant, Vapcomic, and Challenger. On the other hand, all conventional insecticides exhibited low action toward the insect. In addition, the effect of the most potent insecticides on the biochemical criteria of tomato plants revealed that all the examined insecticides significantly reduced the enzymatic and non-enzymatic antioxidants. Moreover, these insecticides led to an increase of the photosynthetic pigments. It was found that the lower the infestation level, the higher the yield and marketable yield. The greater effects were recorded by Emperor and Coragen, while the other insecticides were at par with each another. All the tested insecticides (Radiant, Vapcomic, and Challenger), especially Emperor and Coragen, were effective contra T. absoluta.

\section{Abbreviations \\ LC: Lethal concentration; DAT: Days after treatment; EC: Emulsifiable concentrate; SC: Soluble concentrate; WG: Wettable granules; IRAC: Insecticide Resistance Action Committee; SOD: Super oxide dismutase; CAT: Catalase; PPO: Poly phenol oxidase; mM: Male models; GST: Glutathione S-transferase; CBR: Cost-benefit ratio; Ppm: Part per million; ICBR: Incremental cost-benefit ratio; AL: Alive larvae}

\section{Authors' contributions}

M.A.K, E.A.S, N.F.A-A, E.A., A.M.E-B, and N.M.A designed the experiments, carried out the biological experiments, analyzed the data, and wrote the article. All authors read and approved the final manuscript.

\section{Funding}

This research was financed by the National Research Centre, Egypt, Project No. 11030140

\section{Availability of data and materials}

All data generated or analyzed during this study are included in this article.
Ethics approval and consent to participate

Not applicable (this study does not involve human participants, human data, or human tissue).

\section{Consent for publication}

Not applicable.

\section{Competing interests}

The authors declare that they have no competing interests.

\section{Author details}

${ }^{1}$ Economic Entomology and Pesticide Department, Faculty of Agriculture, Cairo University, Cairo, Egypt. ${ }^{2}$ Department of Pests and Plant Protection, National Research Centre, Cairo, Egypt. ${ }^{3}$ Agricultural and Biological Research Division, Pests and Plant Protection Department, National Research Centre, Cairo, Egypt.

Received: 26 November 2019 Accepted: 13 July 2020

Published online: 28 July 2020

\section{References}

Abbott WS (1925) A method of computing the effectiveness of an insecticide. J. Econ. Entomol. 18:265-267

Abdel-Aziz NF, El-Bakry AM, Metwally NS, Sammour EA, Farrag ARH (2018) Insecticidal efficiency of some green-based formulations on Spodoptera littoralis and their side effects on Albino rats. Asian J Crop Sci 10(4):198-206. https://doi.org/10.3923/ajcs.2018.198.206

Afiyanti M, Chen $\mathrm{H}-\mathrm{J}$ (2014) Catalase activity is modulated by calcium and calmodulin in detached mature leaves of sweet potato. J Plant Physiol 171(2):35-47

Aktar W, Sengupta D, Chowdhury A (2009) Impact of pesticides use in agriculture: their benefits and hazards. Interdisciplinary toxicology 2(1):1-12

Aldea M, Hamilton JG, Resti JP, Zangerl AR, Berenbaum MR, Frank TD et al (2006) Comparison of photosynthetic damage from arthropod herbivory and pathogen infection in understory hardwood saplings. Oecologia 149(2):221-232

Amoabeng BW, Gurr GM, Gitau CW, Stevenson PC (2014) Cost: benefit analysis of botanical insecticide use in cabbage: implications for smallholder farmers in developing countries. Crop Protec 57:71-76

Arnó J, Gabarra R (2010) Controlling Tuta absoluta, a new invasive pest in Europe. Training Integrated Pest Manag 5:1-8

Ayalew G (2015) Efficacy of selected insecticides against the South American tomato moth, Tuta absoluta Meyrick (Lepidoptera: Gelechiidae) on tomato in the Central Rift Valley of Ethiopia. Afr Entomol 23(2):410-418

Bala I, Mukhtar M, Saka H, Abdullahi N, Ibrahim S (2019) Determination of insecticide susceptibility of field populations of tomato leaf miner (Tuta absoluta) in Northern Nigeria. Agriculture 9(1):1-13

Bhonwong A, Stout MJ, Attajarusit J, Tantasawat P (2009) Defensive role of tomato polyphenol oxidases against cotton bollworm (Helicoverpa armigera) and beet armyworm (Spodoptera exiqua). J Chem Ecol 35(1):28-38

Biondi A, Guedes R, Wan F (2018) Ecology, Worldwide Spread, and Management of the Invasive South American Tomato Pinworm, Tuta absoluta: Past, Present, and Future. Annual Review of Entomology (63):239-258. https://doi. org/10.1146/annurev-ento-031616.

CABI (2019) Tomato leafminer (Tuta absoluta): Impacts and coping strategies for Africa. Evidence Note:13

Chen J, Wang X (2006) Plant physiology experimental guide. vol 24-25. Higher Education Press, Beijing, p 55-56

Constabel CP, Barbehenn R (2008) Defensive roles of polyphenol oxidase in plants Induced plant resistance to herbivory. Springer, p 253-270

Dean J, Goodwin P. Hsiang T (2005) Induction of glutathione S-transferase genes of Nicotiana benthamiana following infection by Colletotrichum destructivum and C. orbiculare and involvement of one in resistance. J Exp Bot 56(416):1525-1533

Diaz DH, Martin GC (1972) Peach seed dormancy in relation to endogenous inhibitors and applied growth substances. J Am Soc Hort Sci 17:621-624

Dobrat W, Martijn A (1995) CIPAC handbook volume G: analysis of technical and formulated pesticides. Collaborative International Pesticides Analytical Council

FAOSTAT (2017) Food and agriculture organisation of the United Nations. In. http://www.fao.org/faostat/en/\#data/QC

Finney D (1971) Probit analysis Cambridge Univ. Press, United Kingdom

Fishel F (2002) Effects of water pH on the stability of pesticides Integrated pest management. University of Missouri, Columbia 
Gog L, Berenbaum MR, DeLucia EH, Zangerl AR (2005) Autotoxic effects of essential oils on photosynthesis in parsley, parsnip, and rough lemon. Chemoecology 15(2):115-119

Goławska S, Krzyżanowski R, Łukasik I (2010) Relationship between aphid infestation and chlorophyll content in Fabaceae species. Acta Biologica Cracoviensia Series Botanica 52(2):76-80. https://doi.org/10.2478/v10182 010-0026-4

Gomez SK, Oosterhuis DM, Rajguru SN, Johnson DR, Gomez S (2004) Foliar antioxidant enzyme responses in cotton after aphid herbivory. J Cotton Sci 8(2):99-104

Guedes R, Picanço M (2012) The tomato borer Tuta absoluta in South America: pest status, management and insecticide resistance. EPPO bulletin 42(2):211-216

Guedes R, Roditakis E, Campos M, Haddi K, Bielza P, Siqueira H et al (2019) Insecticide resistance in the tomato pinworm Tuta absoluta: patterns, spread, mechanisms, management and outlook. J Pest Sci:1-14

Habig WH, Pabst MJ, Jakoby WB (1974) Glutathione S-transferases the first enzymatic step in mercapturic acid formation. J Biol Chem 249(22):71307139

Halcomb M (2012) The pH of the Spray Water is Very Important. The University of Tennesse

Harmut A, Lichtenthaler K (1987) Chlorophylls and carotenoids: pigments of photosynthetic membranes. Method Enzymol 148:350-383

Henderson CF, Tilton EW (1955) Tests with acaricides against the brown wheat mite. J Econ Entomol 48(2):157-161

IRAC (2017) (Insecticide Resistance Action Committee). Best management practices to control Tuta absoluta and recommendations to manage insect resistance. Method No: 022

Khattab H, Khattab I (2005) Responses of Eucalypt trees to the insect feeding (Gall forming Psyllid). Int J Agric Biol 7(6):979-984

Kong F, Hu W, Chao S, Sang W, Wang L (1999) Physiological responses of the lichen Xanthoparmelia mexicana to oxidative stress of $\mathrm{SO}_{2}$. Environ Exp Bot 42(3):201-209

Maffei ME, Mithöfer A, Boland W (2007) Insects feeding on plants: rapid signals and responses preceding the induction of phytochemical release. Phytochemistry 68:2946-2959

Mahanil S, Attajarusit J, Stout MJ, Thipyapong P (2008) Overexpression of tomato polyphenol oxidase increases resistance to common cutworm. Plant Sci 174(4):456-466

Mahmoud YA, EBRAHIM M, Aly MM (2004) Influence of some plant extracts and microbioagents on some physiological traits of faba bean infected with Botrytis fabae. Turkish J Botany 28(6):519-528

Metzner H, Rau H, Senger H (1965) Untersuchungen zur Synchronisierbarkeit einzelner Pigmentmangel-Mutanten von Chlorella Studies on synchronization of some pigment-deficient Chlorella mutants. Planta 65(2): 186-194

Mollá O, González-Cabrera J, Urbaneja A (2011) The combined use of Bacillus thuringiensis and Nesidiocoris tenuis against the tomato borer Tuta absoluta. BioControl 56(6):883-891

Nabity PD, Zavala JA, DeLucia EH (2008) Indirect suppression of photosynthesis on individual leaves by arthropod herbivory. Ann Bot 103(4):655-663

Roby AE, Hussein S (2019) Behavior of bio-and chemical insecticides in tomato ecosystem in Minia Governorate. Acta Ecologica Sinica 39(2):152-156

Roditakis E, Skarmoutsou C, Staurakaki M (2013) Toxicity of insecticides to populations of tomato borer Tuta absoluta (Meyrick) from Greece. Pest Manage Sci 69(7):834-840

Sammour EA, Kandil MAH, Abdel-Aziz NF, Agamy EAM, El-Bakry AM, Abdelmaksoud NM (2018) Field evaluation of new formulation types of essential oils against tuta absoluta and their side effects on tomato plants. Acta Sci Agric 2(6):15-22

Shahrtash M (2013) Plant glutathione S-transferases function during environmental stresses: a review article. Romanian J Biol Plant Biol 58(1):19-25

Silva WM, Berger M, Bass C, Balbino VQ, Amaral MH, Campos MR et al (2015) Status of pyrethroid resistance and mechanisms in Brazilian populations of Tuta absoluta. Pestic Biochem Physiol 122:8-14

Simmons AM, Wakil W, Qayyum MA, Ramasamy S, Kuhar TP, Philips CR (2018) Lepidopterous pests: biology, ecology, and management Sustainable Management of Arthropod Pests of Tomato. Elsevier, p 131-162

Soliva RC, Elez P, Sebastián M, Martín O (2000) Evaluation of browning effect on avocado purée preserved by combined methods. Innov Food Sci Emerg Technol 1(4):261-268
SPSS (2017) Statistical package for the social sciences. 25 edn. Chicago, IL, USA Sreekanth M, Lakshmi M, Rao Y (2014) Bio-efficacy and economics of certain new insecticides against gram pod borer, Helicoverpa armigera (Hubner) infesting pigeonpea (Cajanus cajan L.). Int J Plant Animal Environ Sci 4(1):11-15

Sridhar V, Onkaranaik S, Nitin K (2016) Efficacy of new molecules of insecticides against South American tomato moth, Tuta absoluta (Meyrick)(Lepidoptera: Gelechiidae). Pest Manag Horticultural Ecosystems 22(2):137-145

Tang JY, Zielinski RE, Zangerl AR, Crofts AR, Berenbaum MR, DeLucia EH (2005) The differential effects of herbivory by first and fourth instars of Trichoplusia ni (Lepidoptera: Noctuidae) on photosynthesis in Arabidopsis thaliana. J Exp Bot 57(3):527-536

Tayeb E-SH, Abd E-FA, Elbialy MA (2018) Insecticides and their mixtures for controlling Tuta absoluta infesting tomato under Egyptian field conditions. Alexandria Sci Exchange 39(2):215-222

Thipyapong P, Hunt MD, Steffens JC (1995) Systemic wound induction of potato (Solanum tuberosum) polyphenol oxidase. Phytochemistry 40(3):673-676

Venisse J-S, Gullner G, Brisset M-N (2001) Evidence for the involvement of an oxidative stress in the initiation of infection of pear by Erwinia amylovora. Plant Physiol 125(4):2164-2172

WHO (1979) World Health Organization. Specifications for pesticides used in public health: insecticides, molluscicides, repellents, methods, 1St edn

\section{Publisher's Note}

Springer Nature remains neutral with regard to jurisdictional claims in published maps and institutional affiliations.

\section{Submit your manuscript to a SpringerOpen ${ }^{\circ}$ journal and benefit from:}

- Convenient online submission

- Rigorous peer review

- Open access: articles freely available online

- High visibility within the field

- Retaining the copyright to your article

Submit your next manuscript at $>$ springeropen.com 